\title{
KELENGKAPAN PENULISAN DIAGNOSA PADA RESUME MEDIS TERHADAP KETEPATAN PENGKODEAN KLINIS KASUS KEBIDANAN
}

\author{
Aurelius Anugerah Harvey Pepo' ${ }^{1}$, Noor Yulia ${ }^{2}$ \\ ${ }^{1}$ STIKes Santo Borromeus \\ ${ }^{2}$ Universitas Esa Unggul \\ harvey.pepo@gmail.com ${ }^{1}$, noor_yulia15@yahoo.com ${ }^{2}$
}

\begin{abstract}
Purposes of this research is to identify the description of accurate medical coding, to identify the description of complete written diagnosis in medical resume and to identify the relation between complete written diagnosis in patient medical resume with obstetrics cases and accurate medical inpatient coding in Atma Jaya Hospital. Type of research which is used is quantitative with cross sectional method used as a design to collect primary data. Data populations are the medical records of patient with obstetric cases in 2014 which about 819 records and sample calculated are 44 records which calculated by using Beda 2 Proporsi formula. Statistics test used in this research are divided into 2 main parts which are univariate analysis by using distribution frequency and multivariate analysis by using chi square test. Results of the research show us that there are inaccurate medical coding which calculated 50\% and incomplete written diagnosis in patient medical resume in application of health information management practices in Atma Jaya Hospital. And based from relationship test by applying chi square test founded that incomplete written diagnose in medical resume is a factor that influence inaccurate medical coding with $p$ value $=0,000$ and $O R=26,667(95 \% C I=4,727$ 150,428). Conclusion taken are the practice of medical coding so does the completing medical resume in Atma Jaya still need to be improved and complete medical resume is a factor that influence accurate coding.
\end{abstract}

Keyword: accurate, medical coding and complete medical resume

\begin{abstract}
Abstrak
Penelitian ini bertujuan untuk mengidentifikasi gambaran ketepatan pengkodean klinis, gambaran kelengkapan penulisan diagnosa pada resume medis dan hubungan kelengkapan penulisan diagnosa pada resume medis terhadap ketepatan pengkodean klinis pasien dengan kasus kebidanan di Unit Rawat Inap Rumah Sakit Atma Jaya. Metode penelitian yang digunakan adalah kuantitatif dengan menggunakan disain penelitian cross sectional untuk mengumpulkan data primer. Populasi data adalah rekam medis pasien dengan kasus kebidanan pada Tahun 2014 yang berjumlah 819 rekam medis dan sampel yang diteliti adalah sebesar 44 rekam medis yang diperoleh dari hasil perhitungan dengan menggunakan rumus uji 2 beda proporsi. Uji statistik terbagi atas dua kelompok yaitu untuk analisa data univariat dengan menggunakan distribusi frekuensi dan analisa data bivariat dengan menggunakan chi square. Dari penelitian yang telah dilakukan ditemukan hasil sebagai berikut bahwa proporsi ketidaktepatan pengkodean klinis mencapai 50\% dan proporsi ketidaklengkapan penulisan diagnosa pada resume medis mencapai 40,9. Berdasarkan hasil uji hubungan dengan menggunakan uji chi square ditemukan bahwa ketidaklengkapan penulisan diagnosa pada resume medis adalah faktor pengaruh ketidaktepatan pengkodean klinis dengan $p$ value $=0,000$ dan $O R=26,667(95 \% C I=4,727-150,428)$. Kesimpulan yang dapat diambil dari penelitian tersebut adalah bahwa ketepatan pengkodean klinis di Rumah Sakit Atma Jaya adalah 50\% dan kelengkapan penulisan diagnosa pada resume medis sebagai faktor yang mempengaruhi angka ketepatan pengkodean klinis pasien dengan kasus kebidanan di Rumah Sakit Atma Jaya.
\end{abstract}

Kata kunci: ketepatan, pengkodean, kelengkapan dan resume 


\section{PENDAHULUAN}

Dalam Undang-Undang Praktik Kedokteran No.29 Pasal 46 ayat (1) dijelaskan bahwa setiap dokter atau dokter gigi dalam menjalankan praktik kedokteran wajib membuat rekam medis. Tanggung jawab utama akan kelengkapan rekam medis terletak pada dokter dan dokter gigi yang merawat. Dokter dan dokter gigi yang merawat bertanggung jawab akan kelengkapan dan kebenaran isi rekam medis. Dalam mencatat beberapa keterangan medik seperti riwayat penyakit, pemeriksaan fisik dan ringkasan keluar (resume) kemungkinan bisa didelegasikan pada coasisitent asisten ahli dan dokter lainnya. Ketepatan dan kelengkapan data rekam medis pasien harus dipelajari, dikoreksi dan ditandatangani oleh dokter yang merawat. Saat ini banyak rumah sakit menyediakan staf dokter untuk melengkapai rekam medis. Namun demikian tanggung jawab utama dari isi rekam medis tetap berada pada dokter yang merawat. Kelengkapan dalam mencatat keterangan medik dapat mempengaruhi akurasi asuhan pasien di kemudian hari jika hendak melakukan kunjungan ulang dan tentunya berpengaruh terhadap ketepatan pengkodean klinis.

Pengkodean klinis dapat diartikan sebagai satu sistem pengelompokan (categories) penyakit, cedera dan kondisi kesehatan serta prosedur yang disusun sesuai kriteria yang telah ditentukan dan disepakati bersama. Orang yang melakukan klasifikasi atau pengkodean klinis disebut coder. Peran coder adalah untuk melakukan pengkodean klinis yang merupakan penetapan kode dengan menggunakan huruf atau angka atau kombinasi keduanya untuk mewakili komponen data secara akurat.

Berdasarkan penyimpulan dari beberapa jurnal penelitian rekam medis dan informasi kesehatan mengenai ketepatan pengkodean klinis diperoleh rata-rata proporsi ketepatan pengkodean klinis yaitu berkisar pada angka 53\%-88,23\%. Penelitian Hendrajat (2013) di Rumah Sakit Santo Yusup diperoleh hasil proporsi ketidaktepatan $47 \%$ dan ketepatan 53\%. Jurnal Calvin (2013) hasil penelitian di Rumah Sakit Cahya Kawaluyan dengan hasil proporsi ketidaktepatan 11,76\% dan ketepatan 88,23\% . Penelitian lain oleh Yuliani, dkk (2008) di Rumah Sakit Islam Klaten diperoleh hasil proporsi kode yang tepat adalah $66,52 \%$ dan tidak tepat sebesar 33,48\%. Jurnal Astuti (2007) hasil penelitian di badan RSUD Sukoharjo periode triwulan IV dengan hasil ketepatan sebesar $55 \%$ dan yang tidak tepat sebesar $45 \%$. Dan jurnal penelitian oleh Rohman, dkk (2011) hasil penelitian di Rumah Sakit PKU Muhammadiyah Yogyakarta dengan hasil proporsi ketepatan sebesar $81,01 \%$ dan ketidaktepatan $18,99 \%$.

Ketepatan pengkodean klinis dapat dipengaruhi oleh beberapa faktor. Beban kerja adalah salah satu faktor yang mempengaruhi ketepatan pengkodean klinis menurut penelitian dengan hasil uji statistik yang dilakukan oleh Natalia (2013) di Rumah Sakit Santo Borromeus Bandung dan Hertiyanti (2014) di Rumah Sakit Anak dan Bunda Harapan Kita Jakarta. Penelitian Ayu (2012) di RSUD Kota Semarang triwulan I dengan hasil bahwa kelengkapan rekam medis, tenaga medis, tenaga rekam medis, dan sarana adalah faktor-faktor yang mempengaruhi ketepatan pengkodean klinis.Jurnal Setianto (2012) hasil penelitian di Rumah Sakit Permata Medika Semarang diperoleh hasil bahwa spesifikasi penulisan diagnosa utama, kebijakan mengenai singkatan dan mengenai pengisian diagnosa utama dan kurang telitinya petugas koding dalam melakukan analisa adalah faktor yang mempengaruhi ketepatan pengkodean klinis. Tenaga koding dengan perincian pengalaman kerja, latar belakang pendidikan, jumlah pelatihan dan tenaga medis berupa penulisan diagnosis tidak spesifik, ketidaksesuaian hasil pemeriksaan penunjang dangan diagnosa utama, kondisi abnormal pada hasil pemeriksaan penunjang tidak menjadi alasan pertimbangan penegakan diagnosis dan pemberian terapi dalam jurnal Setiawati (2014) hasil penelitian di BKPM wilayah Semarang periode triwulan I dijelaskan sebagai faktor-faktor yang mempengaruhi ketepatan pengkodean klinis. Penelitian Pratama (2014) di RSUD Tugurejo Semarang periode triwulan I diperoleh diagnosis utama yang tidak spesifik, kurangnya komunikasi antara petugas koding dan dokter serta petugas koding yang kurang teliti dalam memberi kode penyakit adalah faktor-faktor yang turut mempengaruhi ketepatan pengkodean klinis. Hasil penelitian Murtisari (2011) di Rumah Sakit Umum Jati Husada Karanganyar periode triwulan I diperoleh hasil bahwa faktorfaktor yang mempengaruhi ketepatan pengkodean klinis adalah tenaga medis, kerja sama antara tenaga medis dan coder dan petugas coding; kemampuan (pengetahuan, latar belakang pendidikan), ketekunan, ketelatenan dan ketelitiannya, alat bantu yaitu daftar ringkasan diagnosis yang sering digunakan di rumah sakit yang kurang spesifik serta suasana 
kerja yang kurang mendukung. Giyana (2009) dalam penelitiannya yang dilakukan di RSUD Kota Semarang menyimpulan bahwa faktor yang mempengaruhi ketepatan kode adalah pengalaman kerja, beban kerja dan sarana kerja. Astuti (2007) dalam penelitiannya di RSUD Sukoharjo menjelaskan faktor yang mempengaruhi yaitu tenaga medis, tenaga rekam medis, lingkungan kerja dan beban kerja. Rohman (2008) pada penelitiannya di Rumah Sakit PKU Muhammadiyah Yogyakarta memaparkan faktor penyebab ketidaktepatan kode diagnosis dapat dilihat dari sisi eksternal dan internal, faktor eksternalnya adalah diagnosis utama tidak ditulis, tulisan dokter yang sulit dibaca, penggunaan singkatan dan istilah-istilah baru. Faktor internalnya adalah petugas kodingnya belum terlalu memahami cara mengkode, basic petugas rekam medis biasanya dari SMA yang tentu saja belum terlalu memahami ilmu penyakit dan istilah-istilah kesehatan, lebihlebih bila ada istilah baru yang tidak sering ditemui kemudian alat bantu (patologi anatomi atau peta anatomi tubuh) dan kamus-kamus kedokteran.

Banyak aktivitas yang esensial bagi suksesnya organisasi asuhan kesehatan bergantung kepada akurasi, integritas dari data yang terkode, di antaranya: perencanaan strategik, akurasi asuhan, analisis keluaran, penagihan biaya rawat, pengembangan critical pathway, inisiasi sehat dan sejahtera, monitoring utilisasi, analisis statistik dan finansial, riset, manajemen kasus dan analisis case-mix, pemasaran dan pengalokasian sumber daya, economic credentialing, identifikasi "praktek terbaik", analisis pola praktik, komparasi penampilan terhadap organisasi asuhan kesehatan lain dan menunjang keputusan klinis (Hatta 2010).

Rumah Sakit Atma Jaya juga memiliki unit rekam medis yang dalam struktur organisasinya termasuk dalam unit penunjang non medis. Unit rekam medis Rumah Sakit Atma jaya juga melaksanakan kegiatan pengkodean klinis untuk berbagai kepentingan. Berdasarkan observasi awal mengenai pengkodean klinis di Rumah Sakit Atma Jaya yang dilakukan terhadap 30 sampel rekam medis diperoleh bahwa proporsi ketidaktepatan pengkodean klinis mencapai $40 \%$ dan proporsi ketepatannya $60 \%$. Mengingat rendahnya proporsi ketepatan pengkodean klinis di Rumah Sakit Atma Jaya dan pentingnya pengkodean klinis karena pemanfaatannya untuk berbagai kepentingan; mulai dari pembuatan laporan, penentuan tarif pelayanan rumah sakit hingga perencanaan dan pengelolaan rumah sakit, kepentingan riset dan pengembangan kebijakan kesehatan oleh rumah sakit. Oleh karena itu, penulis merasa tertarik untuk menganalisa dan meneliti lebih lanjut mengenai "Hubungan Kelengkapan Penulisan Diagnosa Pada Resume Medis Pasien Kasus Kebidanan Terhadap Ketepatan Pengkodean Klinis Rawat Inap Di Rumah Sakit Atma Jaya Tahun 2014".

\section{METODE}

Jenis penelitian yang digunakan dalam penelitian ini adalah deskriptif, desain penelitian yang digunakan adalah cross sectional. Perhitungan sampel pada penelitian ini menggunakan rumus uji 2 beda proporsi dan kemudian didapatkan jumlah sampel yang diteliti adalah sebesar 44 rekam medis pasien kasus kebidanan rawat inap di tahun 2014. Pengambilan sampel menggunakan metode probability sampling yaitu dengan menggunakan teknik sampel random sederhana (simple random sampling. Aplikasi pada penelitian dilakukan dengan membagi sampel dengan jumlah bulan pada satu tahun sehingga besar sampel yang diambil dari tiap bulannya yaitu sama antara 3-4 rekam medis. Pengumpulan data dengan cara observasi.Teknik analisa data dilakukan dengan uji statistik yang terbagi atas dua kelompok yaitu untuk analisa data univariat dengan menggunakan distribusi frekuensi dan analisa data bivariat dengan menggunakan uji chi square.

\section{HASIL}

\section{Ketepatan Pengkodean Klinis Kasus Kebidanan Rawat Inap di Rumah Sakit Atma Jaya}

Tabel 1. Distribusi Ketepatan Pengkodean Klinis Kasus Kebidanan Rawat Inap

\begin{tabular}{llcc}
\hline No & $\begin{array}{c}\text { Ketepatan } \\
\text { Pengkodean Klinis }\end{array}$ & Jumlah & Persentase \\
\hline 1 & Tepat & 22 & $50 \%$ \\
2 & Tidak Tepat & 22 & $50 \%$ \\
\hline
\end{tabular}

Berdasarkan tabel bahwa dari 44 sampel rekam medis pasien rawat inap dengan kasus kebidanan pada tahun 2014 yang telah diteliti ditemukan terdapat $22(50 \%)$ rekam medis yang pengkodean klinisnya tepat dan $22(50 \%)$ rekam medis yang pengkodean klinisnya tidak tepat. 


\section{Kelengkapan Penulisan Diagnosa Pada Resume Medis Pasien Kasus Kebidanan}

Tabel 2. Distribusi Kelengkapan Penulisan Diagnosa Pada Resume Medis Pasien Kasus Kebidanan

\begin{tabular}{clll}
\hline No & $\begin{array}{c}\text { Kelengkapan } \\
\text { Penulisan Diagnosa }\end{array}$ & Frekuensi & Persentase \\
\hline 1 & Lengkap & 26 & $59,1 \%$ \\
2 & Tidak Lengkap & 18 & $40,9 \%$ \\
\hline
\end{tabular}

Berdasarkan tabel 2 bahwa dari 44 sampel rekam medis pasien rawat inap dengan kasus kebidanan pada tahun 2014 yang telah diteliti ditemukan terdapat $26(59,1 \%)$ rekam medis yang penulisan diagnosa pada resume medisnya lengkap dan 18 $(40,9 \%)$ rekam medis yang penulisan diagnosa pada resume medisnya tidak lengkap.

Hubungan Kelengkapan Penulisan Diagnosa Pada Resume Medis Pasien Kasus Kebidanan Terhadap Ketepatan Pengkodean Klinis

Tabel 3. Hubungan Kelengkapan Penulisan Diagnosa Pada Resume Medis Pasien Kasus Kebidanan Terhadap Ketepatan Pengkodean Klinis

\begin{tabular}{|c|c|c|c|c|c|c|c|c|}
\hline \multirow{3}{*}{$\begin{array}{c}\text { Kelengkapan } \\
\text { Penulisan Diagnosa }\end{array}$} & \multicolumn{4}{|c|}{ Ketepatan Pengkodean Klinis } & \multirow{3}{*}{ Jumlah } & \multirow{3}{*}{$p$ Value } & \multirow{3}{*}{$O R$} & \multirow{3}{*}{$95 \% \mathrm{Cl}$} \\
\hline & \multicolumn{2}{|c|}{ Tidak Tepat } & \multicolumn{2}{|c|}{ Tepat } & & & & \\
\hline & $\mathrm{N}$ & $\%$ & $\mathrm{~N}$ & $\%$ & & & & \\
\hline Tidak Lengkap & 16 & $88,9 \%$ & 2 & $11,1 \%$ & 18 & \multirow{3}{*}{0,000} & \multirow{3}{*}{26,667} & \multirow{3}{*}{$\begin{array}{l}4,727- \\
150,428\end{array}$} \\
\hline Lengkap & 6 & $23,1 \%$ & 20 & $76,9 \%$ & 26 & & & \\
\hline Total & 22 & $50 \%$ & 22 & $50 \%$ & 44 & & & \\
\hline
\end{tabular}

Berdasarkan tabel 3 ditunjukan bahwa dari 44 sampel rekam medis pasien kasus kebidanan tahun 2014 terdapat 18 rekam medis yang penulisan diagnosa pada resume medisnya tidak lengkap dengan 16 $(88,9 \%)$ yang pengkodean klinisnya tidak tepat dan $2(11,1 \%)$ yang pengkodean klinisnya tepat. Sedangkan terdapat 26 rekam medis yang penulisan diagnosa pada resume medisnya lengkap dengan $6(23,1 \%)$ yang pengkodean klinisnya tidak tepat sebaliknya terdapat $20(76,9 \%)$ yang pengkodean klinisnya tepat.

Berdasarkan hasil uji chi-square terhadap hubungan kelengkapan penulisan diagnosa pada resume medis pasien kasus kebidanan terhadap ketepatan pengkodean klinis pada unit rawat inap di RS Atma Jaya diperoleh nilai signifikan hasil uji statistik yaitu $p$ value $=0,000$. Karena nilai $p$ value $(0,000)$
$<0,05$ maka $\mathrm{H}_{0}$ ditolak yang artinya ada hubungan kelengkapan penulisan diagnosa pada resume medis pasien kasus kebidanan terhadap ketepatan pengkodean klinis rawat inap. Lembaran resume medis yang memiliki dokumentasi diagnosa yang lengkap akan menunjang ketepatan pengkodean klinis. Begitu pula sebaliknya dimana penulisan diagnosa pada resume medis pasien yang tidak lengkap dapat berpengaruh terhadap ketidaktepatan pengkodean klinis.

Dari tabel 2 dapat dilihat bahwa nilai OR (Odds Ratio) adalah 26,667 (95\% CI: 4,727-150,428). Nilai $O R$ tersebut dapat diinterpertasikan sebagai berikut bahwa rekam medis yang mendokumentasikan diagnosa pada resume medis secara lengkap menunjang ketepatan pengkodean klinis 26,667 lebih besar dibandingkan dengan penulisan diagnosa pada resume medis pasien yang tidak lengkap.

\section{PEMBAHASAN}

\section{Ketepatan Pengkodean Klinis Kasus Kebidanan Rawat Inap}

Ketepatan adalah suatu hal, keadaan dan sifat tepat; kecermatan; ketelitian yang jitu, sesuai, kena benar dan tidak ada selisih sedikitpun. Pengkodean klinis adalah satu sistem pengelompokkan (categories) penyakit, cedera dan kondisi kesehatan serta prosedur yang disusun sesuai kriteria yang telah ditentukan dan disepakati bersama yang dalam hal ini adalah $I C D$-10 dan ICD $9 C M$. Ketepatan pengkodean klinis adalah apabila kode yang dihasilkan dari kegiatan pengkodean klinis mewakili diagnosa pasien sesuai dengan apa yang terdapat dalam $I C D-10$.

Pengkodean klinis haruslah tepat dengan alasan bahwa kode hasil kegiatan pengkodean klinis merupakan data dasar bagi institusi kesehatan yang bila dikelola secara tepat akan memberikan manfaat bagi institusi pelayanan kesehatan baik secara langsung maupun tidak langsung. Manfaat tersebut antara lain adalah untuk perencanaan strategik, akurasi asuhan, analisis keluaran, penagihan biaya rawat, pengembangan critical pathway, inisiasi sehat dan sejahtera, monitoring utilisasi, analisis statistik dan finansial, riset, manajemen kasus dan analisis case-mix, pemasaran dan pengalokasian sumber daya, economic credentialing, identifikasi "praktek terbaik", analisis pola praktik, komparasi penampilan terhadap organisasi asuhan kesehatan lain dan 
menunjang keputusan klinis. Sehingga apabila suatu institusi mengalami permasalahan dalam ketepatan pengkodean klinis maka akan berpengaruh terhadap manfaat-manfaat tersebut.

Berdasarkan penelitian yang telah dilakukan mengenai ketepatan pengkodean klinis kasus kebidanan pada tahun 2014 di Rumah Sakit Atma Jaya diperoleh hasil dimana terdapat 22 rekam medis $(50 \%)$ dengan pengkodean klinis yang tepat dan rekam medis (50\%) dengan pengkodean klinis yang tidak tepat. Proporsi ketepatan pengkodean klinis tersebut masih terbilang kecil dan merupakan permasalahan yang harus segera diselesaikan di Rumah Sakit Atma Jaya.

Pemanfaatan kode diagnosis klinis sebagai data dasar dalam pembuatan laporan dan pembayaran biaya kesehatan. Laporan yang dimakud adalah laporan bulanan diagnosa pasien rawat inap (RL2a \& RL2a1) dan rawat jalan (RL2b \& RL2b1) yang dilaporkan kepada dinas kesehatan dan juga dimanfaatkan untuk dasar pengambilan keputusan pada berbagai tingkatan manajemen atau bagian-bagian tertentu di Rumah Sakit Atma Jaya. Pengkodean klinis juga dimanfaatkan untuk menentukan besaran tarif pembiayaan kesehatan karena Rumah Sakit Atma Jaya juga bekerja sama dengan BPJS dalam penyelenggaraan pelayanan kesehatannya. Jaminan Kesehatan Nasional (JKN) yang diselenggarakan BPJS menggunakan sistem INA-CBGs dimana satuan besaran pembayaran pelayanan kesehatan ditentukan oleh diagnosa yang telah dikode dengan $I C D-10$ sehingga apabila terjadi kesalahan dalam kegiatan pengkodean klinis akan memberikan dampak pada besaran satuan pembayaran klinis.

\section{Kelengkapan Penulisan Diagnosa Pada Resume Medis Pasien Kasus Kebidanan}

Pernyataan diagnosa dibuat dalam rekam medis yang mencerminkan tingkat pengertian mengenai kondisi medis pasien saat direkam. Resume medis adalah bagian dari berkas rekam medis yang berupa lembaran berisi tentang informasi penting tentang penyakit, pemeriksaan dan pengobatan sejak pasien masuk, dirawat, sampai pasien pulang. Resume medis adalah lembar alternatif yang berisi semua informasi penting terkait pasien oleh karena itu harus didokumentasikan dengan lengkap. Resume medis dikatakan sebagai alternatif karena lembar resume medis mewakili seluruh keadaan dan pengobatan yang dialami pasien saat diasuh di rumah sakit.
Kelengkapan penulisan diagnosa pada resume medis adalah penting karena resume medis pasien adalah alat komunikasi antar berbagai tenaga medis mengenai kondisi klinis pasien yang akan digunakan apabila pasien hendak berobat lagi dikemudian hari. Diagnosa yang ditulis lengkap pada resume medis mencerminkan ketepatan dan pemahaman yang tinggi akan kondisi pasien oleh tenaga medis sehingga tidak menimbulkan kerancuan apabila tenaga medis lain akan memberikan perawatan pada pasien di kemudian hari. Kelengkapan penulisan diagnosa pada resume medis juga dapat membantu coder dalam melaksanakan pengkodean klinis. Penulisan diagnosa yang lengkap dan spesifik dapat menjamin ketepatan pengkodean klinis. Selain itu, resume medis juga digunakan oleh pihak ketiga berupa asuransi untuk mengetahui kualitas asuhan pelayanan kesehatan yang diberikan oleh tenaga medis terhadap pasien pada suatu institusi kesehatan seperti rumah sakit. Resume medis yang lengkap mencerminkan tingkat pemahaman tinggi akan kondisi pasien oleh tenaga medis dan mengambarkan baiknya kualitas pelayanan yang diberikan di rumah sakit.

Berdasarkan penelitian mengenai kelengkapan penulisan diagnosa pada resume medis pasien kasus kebidanan di Rumah Sakit Atma Jaya diperoleh hasil dimana terdapat 26 rekam medis $(59,1 \%)$ yang penulisan diagnosanya tidak lengkap dan 18 rekam medis $(40,9 \%)$ yang penulisan diagnosanya lengkap.

Persentase kelengkapan penulisan diagnosa pada resume medis yang rendah akan menyebabkan terganggunya proses komunikasi antar tenaga medis karena kondisi pasien tidak digambarkan secara lengkap dan spesifik melalui diagnosa pada resume medis. Selain itu akan mempengaruhi kerja sama rumah sakit dengan pihak asuransi karena ketidaklengkapan penulisan diagnosa pada resume medis mencerminkan kurang pahamnya tenaga medis khususnya dokter terhadap kondisi medis pasien. Dan angka kelengkapan penulisan diagnosa yang rendah akan mempengaruhi ketepatan pelaksanaan pengkodean klinis oleh coder karena diagnosa pada resume medis merupakan dasar pelaksanaan pengkodean klinis.

\footnotetext{
Hubungan Kelengkapan Penulisan Diagnosa Pada Resume Medis Pasien Kasus Kebidanan Terhadap Ketepatan Pengkodean Klinis
} 
Berdasarkan hasil uji chi-square terhadap hubungan kelengkapan penulisan diagnosa pada resume medis pasien kasus kebidanan terhadap ketepatan pengkodean klinis pada unit rawat inap di RS Atma Jaya diperoleh nilai signifikan hasil uji statistik yaitu $p$ value $=0,000$ dengan nilai $O R=26,667(95 \%$ $C I: 4,727-150,428)$. Karena nilai $p$ value $(0,000)$ $<0,05$ maka $\mathrm{H}_{0}$ ditolak yang artinya ada hubungan kelengkapan penulisan diagnosa pada resume medis pasien kasus kebidanan terhadap ketepatan pengkodean klinis rawat inap. Lembaran resume medis yang memiliki dokumentasi diagnosa yang lengkap akan menunjang ketepatan pengkodean klinis. Begitu pula sebaliknya dimana penulisan diagnosa yang tidak lengkap pada resume medis pasien dapat berpengaruh terhadap ketidaktepatan pengkodean klinis.

Hubungan antara kelengkapan penulisan diagnosa pada resume medis terhadap ketepatan pengkodean klinis yang telah diuji peneliti pada penelitian ini sejalan dengan penelitian yang telah dilakukan oleh Ayu (2012) mengenai tinjauan penulisan diagnosis utama dan ketepatan kode $I C D-10$ pada pasien umum di RSUD Kota Semarang Triwulan I Tahun 2012, Setianto (2012) mengenai tinjauan keakuratan penetapan kode diagnosis utama berdasarkan spesifikasi penulisan diagnosa utama pada dokumen rekam medis rawat inap di Rumah Sakit Permata Medika Semarang Periode 2012, Setiawati (2014) mengenai tinjauan akurasi kode diagnosa utama menurut $I C D-10$ pada dokumen rekam medis rawat jalan di BKPM Wilayah Semarang Periode Triwulan I Tahun 2014, Hidayah (2014) mengenai accuracy analysis of primary diagnosis code based on patients BPJS cause unverified in Permata Hospital Medika Semarang Month january 2014, Pratama (2014) mengenai tinjauan hubungan antara spesifisitas diagnosis utama dengan akurasi kode kasus penyakit bedah di RSUD Tugurejo Semarang periode triwulan I Tahun 2014, Maiga (2009) mengenai peran pengetahuan dan sikap dokter dalam ketepatan koding diagnosis berdasar ICD 10, dan oleh Purwitasari (2014) mengenai analisis ketepatan kode diagnosis dan tindakan pasien rawat inap JKN di Rumah Sakit Bhayangkara POLDA DIY.

Lembaran resume medis yang memiliki dokumentasi diagnosa yang lengkap akan menunjang ketepatan pengkodean klinis. Begitu pula sebaliknya dimana penulisan diagnosa yang tidak lengkap pada resume medis pasien dapat berpengaruh terhadap ketidaktepatan pengkodean klinis. Hal tersebut disebabkan karena diagnosa yang tertera pada resume medis merupakan dasar bagi coder dalam melakukan kegiatan pengkodean klinis. Diagnosa yang tidak lengkap, selain dapat menambah waktu dan beban kerja coder karena harus membaca keseluruhan rekam medis untuk memahami keadaan yang dialami pasien sebelum melakukan pengkodean klinis, juga dapat mempengaruhi ketepatan pengkodean klinis karena diagnosa yang tidak lengkap menggambarkan tingkat spesifikasi yang rendah yang sangat berpengaruh terhadap spesifikasi nomor kode yang akan diberikan.

\section{SIMPULAN}

Ada hubungan kelengkapan penulisan diagnosa pada resume medis pasien kasus kebidanan terhadap ketepatan pengkodean klinis kebidanan rawat inap di Rumah Sakit Atma Jaya.

\section{DAFTAR PUSTAKA}

Arikunto, Suharsimi. 2006. Prosedur Penelitian Suatu Pendekatan Praktik. Jakarta: Pt. Rineka Cipta.

Artmanda, F. W. 2007. Kamus Lengkap Bahasa Indonesia. Jombang: Lintas Media.

Asih, Y (ed.). 1997. Kamus Keperawatan. (17 $7^{\text {th }}$ ed.). Jakarta: Penerbit Buku Kedokteran EGC.

Alimul, A. H. 2008. Metode Penelitian Keperawatan dan Teknik Analisis Data. Jakarta: Salemba Medika.

Badudu, J.S. 1996. Kamus Besar Bahasa Indonesia. Jakarta: Pustaka Sinar Harapan.

Departemen Pendidikan Nasional Indonesia. 2008. Kamus Besar Bahasa Indonesia Edisi Keempat. Jakarta: Gramedia Pustaka Utama.

Direktorat Jendral Bina Pelayanan Medik. 2006. Pedoman Penyelenggaraan dan Prosedur Rekam Medis Rumah Sakit di Indonesia Revisi 2. Jakarta: Depkes RI

Hartono, H (ed.). 2000. Kamus Kedokteran Dorland. (29 ${ }^{\text {th }}$ ed.). Jakarta: Penerbit Buku Kedokteran EGC.

2000. Kamus Saku Mosby Kedokteran, Keperawatan \& Kesehatan. (4 ${ }^{\text {th }}$ ed.). Jakarta: Penerbit Buku Kedokteran EGC. 
Hatta, G. R. 2010. Pedoman Manajemen Informasi Kesehatan di Sarana Pelayanan Kesehatan. Jakarta: Penerbit Universitas Indonesia (UIPress).

Keputusan Mentri Kesehatan Republik Indonesia Nomor 129/Menkes/Sk/II/2008 tentang Standar Pelayanan Minimal Rumah Sakit.

Naga, M. A 2013. Buku Kerja Praktik Pengkodean Klinis Berdasarkan Rules Dan Konvensi ICD10, WHO (Cumulative Official Update To ICD-10, October 2003 - Januari 2013 Who, Update And Revision Committee)

Notoatmodjo, S. 2005. Metodologi Penelitian Kesehatan. Jakarta: Rineka Cipta.

Nursalam \& Siti Priani. 2001. Pendekatan Praktis Metodologi Riset Keperawatan. Jakarta: CV. Sagung Seto.

Nursalam. 2009. Konsep dan Penerapan Metodologi Penelitian Ilmu Keperawatan Pedoman Skripsi, tesis, dan Instrumen Penelitian Keperawatan. Jakarta: Salemba Medika.

Peraturan Mentri Kesehatan Republik Indonesia Nomor 269/Menkes/Per/III/2008 tentang Rekam Medis.

Peraturan Menteri Pendayagunaan Aparatur Negara Dan Reformasi Birokrasi Republik Indonesia Nomor 30 Tahun 2013 tentang Jabatan Fungsional Perekam Medis dan Angka Kreditnya

Sabarguna, B. S. 2009. Buku Pegangan Mahasiswa Manajemen Rumah Sakit v Jilid I . Jakarta: CV Sagung Seno.
Siregar, S. 2013. Metode Penelitian Kuantitatif: Dilengkapi Perbandingan Perhitungan Manual \& SPSS. Jakarta: Kencana Prenada Medika Group

Sugiono. 2012. Metode Penelitian Kuantitatif Dan Kualitatif Dan R\&D. Bandung: Penerbit Alfabeta.

Undang-Undang Republik Indonesia Nomor 29 Tahun 2004 Tentang Praktik Kedokteran.

Widjaya, L. 2014. Manajemen Informasi Kesehatan 3: Peningkatan Kelengkapan Pendokumentasian Klinis. Jakarta.

World Health Organization. 2010. International Statistical Classification of Diseases and Related Health Health Problems Volume 1 Tabular List (Tenth Revision). Geneva. 2010. International Statistical Classification of Diseases and Related Health Health Problems Volume 2 Instruction Manual (Tenth Revision). Geneva.

2010. International Statistical Classification of Diseases and Related Health Health Problems Volume 3 Alphabetical Index (Tenth Revision). Geneva.

2010. Improving the quality and use of birth, death and cause-ofdeath information: guidance for a standardsbased review of country practices. Geneva. 